\title{
Role of Piperine as an Effective Bioenhancer in Drug Absorption
}

Mhaske DB*, Sreedharan S and Mahadik KR

Department of Pharmaceutical Chemistry, Bharati Vidyapeeth (Deemed to be) University, Pune, Maharashtra, India

\begin{abstract}
Bioenhancers can be defined as chemical entities, which when mixed with drugs promote and augment their bioavailability without showing any synergistic effect with the drug. The factors like toxicity, cost, poor bioavailability and long term administration of drugs give rise to the need of bioenhancers which help overcome most of these problems. Piper species produce a pungent alkaloid named Piperine or 1-peperoyl piperidine. Piperine increases permeability at the site of absorption by modulating lipid environment and membrane dynamics. Piperine has a molecular structure that is suitable for enzyme inhibition. It augments the bioavailability of several drugs like carbamazepine, curcumin, ciprofloxacin, ampicillin, metronidazole, oxytetracycline and many others by inhibiting various metabolizing enzymes. Thus piperine, being an efficacious inhibitor of drug metabolism is a powerful enhancer of absorption. The following review explores the mechanism, metabolism inhibition, influence of structural changes on activity, and drugs bioenhanced by piperine. It provides an insight on the application of piperine as an effective bioenhancer and the superiority of a bioenhanced drug formulation over the one without a bioenhancer. This concept which is found to be beneficial, has its roots in Ayurveda-the traditional Indian system of medicine and has been applied to various drugs. It presents a fine instance of the advantage of amalgamating a traditional system with contemporary medicine.
\end{abstract}

Keywords: Bioenhancer; Piperine; Molecular structure; Metabolism inhibition

\section{Introduction}

Bioenhancers can be defined as chemical entities, which when mixed with drugs promote and augment their bioavailability without showing any synergistic effect with the drug [1]. Piperine was discovered in 1819 by Hans Christian Orsted, who isolated it from the fruits of Piper nigrum, the source plant of both the black and white pepper grains. The plants belonging to species like Piper nigrum and Piper longum of the Piperaceae family produce piperine which is an alkaloid with a pungent taste [2].

Piperine or 1-peperoyl piperidine is a solid having the molecular formula $\mathrm{C}_{17} \mathrm{H}_{19} \mathrm{O}_{3} \mathrm{~N}$, melting point $128^{\circ} \mathrm{C}$ and is optically inactive, sparingly soluble in water with cis-trans isomerism [3]. It shows high lipophilicity, is weakly basic, and exhibits non-saturable passive absorption kinetics [4]. In 1979, Indian scientists at the Regional Research Laboratory (Indian Institute of Integrative Medicine) in Jammu discovered piperine as the first bioenhancer in the world and also coined the term bioavailability enhancer. In November 2009, the formulation named Risorine that contains $200 \mathrm{mg}$ of rifampicin, $300 \mathrm{mg}$ of isoniazid and $10 \mathrm{mg}$ of piperine was launched by Cadila Pharma in India. The bioavailability of rifampicin was increased by about $60 \%$ with the use of piperine. Thus, due to the addition of bioenhancer piperine the dose of rifampicin is reduced from 450 to $200 \mathrm{mg}$ [5]. Piperine when used in combination with various drugs reduces dose, side effects and increases bioavailability $[6,7]$.

\section{Mechanism of Action of Piperine as a Bioenhancer}

Some mechanisms which have been proposed for the bioenhancing effect of piperine are as follows-

\section{Increased gastrointestinal absorption}

This is brought about by

a. By enhancing solubility: Bile acid aids in the formation of micelle, required for the absorption of lipids and lipid soluble drugs. Piperine enhances the secretion of bile acids and also causes inhibition of bile acid metabolism thereby increasing the formation of micelle. This enhances solubility and absorption [8]. b. Increased blood supply: In a study by Annamalai et al. [9] it has been proposed that trikatu enhances gastrointestinal blood flow which causes increased absorption of drugs from the digestive tract.

c. Increased permeability due to epithelial cell modification: Piperine by interacting with intestinal epithelial cells, stimulates gamma-glutamyl transpeptidase activity and causes an increase in amino acid uptake by epithelial cells [10].

d. It has also been proposed that piperine increases brush border membrane fluidity and increases microvilli length [11].

\section{Efflux of drugs from site of action is reduced}

A study done by Bharadwaj et al. [12] shows that piperine increases the stay of a drug at the active site by inhibiting human p-glycoprotein, which is a major efflux pump.

\section{Inhibition of solubilizer attachment}

When substances are chemically linked to a highly water soluble substance, their entry in the cells is prevented. This is termed as solubilizer attachment. The substances bound to glucuronic acid, which is an important solubilzer are excreted either into the urine or small intestine. It has been reported that piperine inhibits glucuronic acid thus facilitating increased entry of substances into the cell [13].

\section{Reduced metabolism}

a. It has been found that piperine is capable of inhibiting many different cytochrome P-450 isoforms along with UDP-

*Corresponding author: Dr. Deepali Bansode Mhaske, Department of Pharmaceutical Chemistry, Bharati Vidyapeeth (Deemed to be) University, Pune, Maharashtra, India, Tel: +91-9970002387; E-mail: deepali_mhaske@rediffmail.com

Received July 09, 2018; Accepted July 20, 2018; Published July 27, 2018

Citation: Mhaske DB, Sreedharan S, Mahadik KR (2018) Role of Piperine as an Effective Bioenhancer in Drug Absorption9: 591. doi: 10.4172/2153-2435.1000591

Copyright: (C2018 Mhaske DB, et al. This is an open-access article distributed under the terms of the Creative Commons Attribution License, which permits unrestricted use, distribution, and reproduction in any medium, provided the original author and source are credited. 
glucuronyltransferase and hepatic arylhydrocarbon hydroxylase. It inhibits glucuronidation, a metabolic step by inhibiting the enzyme UDP-glucose dehydrogenase $[14,15]$.

b. It has also been proposed that piperine is a selective inhibitor of cytochrome P450 enzyme isoforms like CYP1A1, CYP1A2, CYP2C8, CYP2D6, and CYP3A4 [16].

c. Piperine has also been found to inhibit various mixed function oxygenases [17].

\section{Metabolism Inhibition and Structure Activity Relationship}

Piperine inhibited CYP450, cytochrome and NADPH cytochrome $C$ reductase [18] and major metabolizing enzyme CYP3A4, which is responsible for the first pass metabolism of drugs [12]. It inhibits drug metabolism in a non-specific way and does not show much bias between different CYP450 forms [19]. It is found to inhibit rat CYP4502B1 which converts aflatoxin B1 to cytotoxic and genotoxic metabolite. Thus piperine increases the bioavailability of parent aflatoxin B1 and produces chemoprotective effect against procarcinogens activated by CYP4502B1 [20].

The enzyme inhibition caused by piperine can be attributed to its structure. The structure comprises of three parts namely the methylenedioxyphenyl (MDP) ring, side chain and the piperidine moiety that are together essential for maximal inhibition of both aryl hydrocarbon hydroxylase $(\mathrm{AHH})$ and 7-methoxycoumarin-Odemethylase (MOCD) activity. The modification of any one moiety in the piperine molecule may not only alter the status of inhibition but also could elicit differential inhibition of the two types of monooxygenase activities. Flexibility can be induced in the molecule by saturating piperine side chain which may aid the interaction of protein domain with the inactivator. The conjugated double bonds can be saturated to tetrahydro derivatives of MDP ring resulting in greater flexibility of the side chain. It is believed that this chain perhaps acts as a handle to orient MDP group to the active site of the CYP450. This is anchored in a strongly hydrophobic environment whose interaction with piperine can be determined by altering its functional groups. This would help to determine the specificity and extent of inhibition.

It appears that the presence of the side chain with saturated double bonds linked through amide linkage impart specificity for inhibiting different forms of CYP450's. The structure of piperine as given in (Figure 1 ) is ideally suited to affect the microsomal oxidation of large number of compounds. The sensitivity in inhibition of the CYP450 activities can be discriminated due to the presence of piperidine function and MDP ring [21]. In a study by Pfund LY, it has been revealed that piperine is trimorphic. The two novel polymorphs of piperine show increased solubility as compared to the commercial polymorph, thus enhancing its efficacy as a bioenhancer. The $\pi-\pi$ interactions are present in the newly discovered forms whereas lacking in the commercial form despite the presence of extended conjugation [22].

\section{Updates on Use of Piperine as a Bioenhancer}

Literature survey revealed the following articles listed in (Table 1), which provided information on the use of piperine as a bioenhancer.

\section{Case Studies}

In a study by Atal $\mathrm{S}$ et al. the bioenhancing effect of piperine along with metformin on lowering the blood glucose level was evaluated in

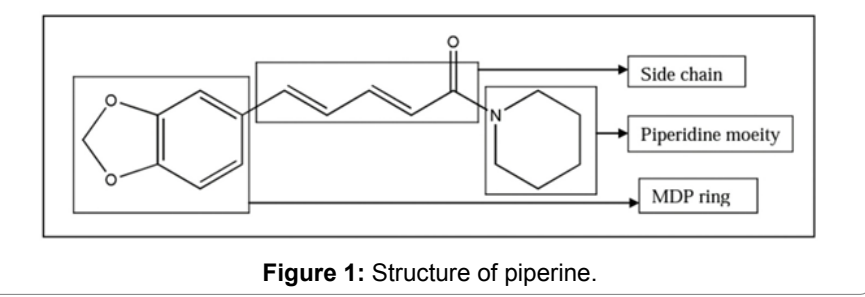

\begin{tabular}{|c|c|c|}
\hline S.No. & Article Title & $\begin{array}{l}\text { Journal name and } \\
\text { year of publication }\end{array}$ \\
\hline 1. & $\begin{array}{l}\text { Enhancement of oral bioavailability and immune } \\
\text { response of Ginsenoside Rh2 by co-administration } \\
\text { with piperine. }\end{array}$ & $\begin{array}{l}\text { Chinese Journal of } \\
\text { Natural Medicines, } \\
2018 \text { [23]. }\end{array}$ \\
\hline 2. & $\begin{array}{l}\text { Piperine-mediated drug interactions and } \\
\text { formulation strategy for piperine: recent advances } \\
\text { and future perspectives. }\end{array}$ & $\begin{array}{l}\text { Expert opinion on } \\
\text { drug metabolism and } \\
\text { toxicity, } 2018[24] \text {. }\end{array}$ \\
\hline 3. & $\begin{array}{c}\text { Piperine in combination with quercetin halt } \\
\text { 6-OHDA induced neurodegeneration in } \\
\text { experimental rats: Biochemical and neurochemical } \\
\text { evidences. }\end{array}$ & $\begin{array}{c}\text { Neuroscience } \\
\text { Research, } 2018 \text { [25]. }\end{array}$ \\
\hline 4. & $\begin{array}{l}\text { Investigation of Need of Natural Bioenhancer for } \\
\text { a Metabolism Susceptible Drug-Raloxifene, in a } \\
\text { Designed Self-Emulsifying Drug Delivery System. }\end{array}$ & $\begin{array}{c}\text { AAPS PharmSciTech, } \\
2017 \\
{[26] .}\end{array}$ \\
\hline 5. & $\begin{array}{c}\text { Role of Risorine in the Treatment of Drug- } \\
\text { Susceptible Pulmonary Tuberculosis: A Pilot Study. }\end{array}$ & $\begin{array}{l}\text { J Assoc Physicians } \\
\text { India. 2016, [27]. }\end{array}$ \\
\hline 6. & $\begin{array}{c}\text { Bio-enhancing Effect of Piperine with Metformin on } \\
\text { Lowering Blood Glucose Level in Alloxan Induced } \\
\text { Diabetic Mice. }\end{array}$ & $\begin{array}{c}\text { Pharmacognosy } \\
\text { Research, } 2016 \text { [28]. }\end{array}$ \\
\hline 7. & $\begin{array}{l}\text { Piperine containing floating microspheres: } \\
\text { an approach for drug targeting to the upper } \\
\text { gastrointestinal tract. }\end{array}$ & $\begin{array}{l}\text { Drug delivery and } \\
\text { translational research, } \\
2016 \text { [29]. }\end{array}$ \\
\hline 8. & $\begin{array}{l}\text { Antioxidant and hepatoprotective effects of } \\
\text { mixed micellar lipid formulation of phyllanthin } \\
\text { and piperine in carbon tetrachloride-induced liver } \\
\text { injury in rodents. }\end{array}$ & $\begin{array}{l}\text { Food and function, } \\
2015 \text { [30]. }\end{array}$ \\
\hline 9. & $\begin{array}{l}\text { Effect of piperine on the bioavailability and } \\
\text { pharmacokinetics of emodin in rats. }\end{array}$ & $\begin{array}{l}\text { J Pharm Biomed } \\
\text { Analysis, } 2015 \text { [31]. }\end{array}$ \\
\hline 10. & The Bioenhancer Piperine is at Least Trimorphic. & $\begin{array}{l}\text { Crystal growth and } \\
\text { design, } 2015 \text { [23]. }\end{array}$ \\
\hline
\end{tabular}

Table 1: List of review articles and research papers describing the use of piperine as a bioenhancer.

alloxan induced diabetic mice. The results showed that piperine (10 $\mathrm{mg} / \mathrm{kg}$ ) in combination with metformin (sub-therapeutic dose of 125 $\mathrm{mg} / \mathrm{kg}$ ) produced significantly higher lowering of blood glucose when compared to control group. It was also reported that the combination produced more lowering of blood glucose as compared to metformin $(250 \mathrm{mg} / \mathrm{kg})$ [28].

In another study by Sethiya NK et al. it was reported that piperine significantly influenced the bioavailability of Phyllanthin which is a sparingly water-soluble hepatoprotective lignin. Phyllanthin was combined with piperine and was formulated as a mixed micellar lipid formulation in the study and investigated to enhance hepatoprotective effects on oral administration and resolve the issue of low bioavailability [30].

\section{Piperine and Bioenhanced Drugs}

The bioavailability and bioefficacy of many drugs has been effectively potentiated by piperine as given in (Table 2). Piperine has the ability to inhibit several enzyme mediated pathways and biotransformation reactions.

\section{Summary and Conclusion}

Bioenhancers embody a fruitful and productive concept which results in enhancement of bioavailability along with reduced dose 
Citation: Mhaske DB*, Sreedharan S, Mahadik KR (2018) Role of Piperine as an Effective Bioenhancer in Drug Absorption9: 591. doi: 10.4172/21532435.1000591

Page 3 of 4

\begin{tabular}{|c|c|c|}
\hline S.No. & Drugs & Experimental model \\
\hline 1. & Vasicine & Rats [32] \\
\hline 2. & Pyrazinamide & In vitro [33] \\
\hline 3. & Phenytoin, propranolol, theophylline & Humans $[34,7]$ \\
\hline 4. & Curcumin & In vivo [35] \\
\hline 5. & Nimesulide & Mice [36] \\
\hline 6. & Indomethacin & Rabbits [37] \\
\hline 7. & Oxyphenylbutazone & Rats [38] \\
\hline 8. & Phenytoin & Human volunteers $[39,40]$ \\
\hline 9. & Rifampicin & Human [41] \\
\hline 10. & EGCG [(-)-epigallocatechin-3-gallate] & Mice [42] \\
\hline 11. & Oxytetracycline & White Leghorn hens [43] \\
\hline 12. & Ciprofloxacin & Rabbits [44] \\
\hline 13. & Fexofenadine & Rats [45] \\
\hline 14. & Nevirapine & Human [46] \\
\hline 15. & Pefloxacin & Gaddi goats [47] \\
\hline 16. & Carbamazepine & In vitro [6] \\
\hline 17. & Metronidazole & Rabbits [48] \\
\hline 18. & Ampicillin trihydrate & Human [49] \\
\hline 19. & Resveratrol & Mice [50] \\
\hline 20. & Gatifloxacin & Layer birds [51] \\
\hline 21. & Atenolol & Rats [52] \\
\hline 22. & Ibuprofen & In vitro [53] \\
\hline 23. & Losartan potassium & Rats [54] \\
\hline
\end{tabular}

Table 2: Drugs that show increased bioavailability when combined with piperine.

and other adverse effects. Various research articles and reviews opine that piperine which inhibits human P-glycoprotein and CYP3A4 is an effective bioenhancer. A wide variety of drugs can be bioenhanced by using piperine.

This review implies that, formulations containing a bioenhancer like piperine are much more effective and suitable as compared to the ones without it. Risorine is one of the best example which utilizes the concept of bioenhancer to help reduce drug dose and side effects along with increased bioavailability. The concept of action of piperine as a bioenhancer should be explored further, as it is quite obvious from literature that piperine has a prospective future as one of the most effective and widely applicable bioenhancer.

\section{References}

1. Patil UK, Singh A, Chakraborty AK (2011) Role of piperine as a bioavailability enhancer. Int J Recent Adv Pharm Res 4: 16-23.

2. Oersted (1820) Über das Piperin, einneuesPflanzenalkaloid. Schweigger's J fürChemie und Physik 29: 80-82.

3. Agarwal O (2010) Alkaloids In: Chemistry of organic natural products.

4. Khajuria A, Zutshi U, Bedi KL (1998) Permeability characteristics of piperine on oral absorption-an active alkaloid from peppers and a bioavailability enhancer. Ind J Exp Biol 36: 46-50.

5. Atal N, Bedi KL (2010) Bioenhancers: Revolutionary concept to market. J Ayur Int Med 1: 96-99.

6. Amar S, Pawar VK, Vikash J, Parabia MH, Rajendra A, et al. In-vivo assessment of enhanced bioavailability of metronidazole with piperine in rabbits. Res $\mathrm{J}$ Pharm Biol Chem Sci 1: 273-278.

7. Bano G, Raina RK, Zutshi U, Bedi KL, Johri RK, Sharma SC (1991) Effect of piperine on bioavailability and pharmacokinetics of propranolol and theophylline in healthy volunteers. Eur J Clin Pharmacol 41: 615-617.

8. Lee KW, Everts H, Beynen AC (2004) Essential oils in broiler nutrition. Int J Poult Sci 3: 738-752.

9. Annamalai AR, Manavlan R (1989) Trikatu- A bioavailability enhancer. Ind Drugs 27: 595-604.

10. Johri RK, Thusu N, Khajuria A, Zutshi U (1992) Piperine-mediated changes in the permeability of rat intestinal epithelial cells: the status of $y$-glutamy transpeptidase activity, uptake of amino acids and lipid peroxidation. Biochem Pharmacol 43: 1401-1407.

11. Khajuria A, Thusu N, Zutshi U (2002) Piperine modulates permeability characteristics of intestine by inducing alterations in membrane dynamics: Influence on brush border membrane fluidity, ultrastructure and enzyme kinetics. Phytomedicine 9: 224-231.

12. Bhardwaj RK, Glaeser H, Becquemont L, Klotz U, Gupta SK, et al. (2002) Piperine, a major constituent of black pepper, inhibits human P-glycoprotein and CYP3A4. J Pharmacol Exp Ther 302: 645-650.

13. Reen RK, Singh J (1991) In vitro and in vivo inhibition of pulmonary cytochrome P450 activities by piperine, a major ingredient of piper species. Indian J Exp Biol 29: 568-573.

14. Singh J, Dubey RK, Atal CK (1986) Piperine-mediated inhibition of glucuronidation activity in isolated epithelial cells of the guinea-pig small intestine: Evidence that piperine lowers the endogeneous UDP-glucuronic acid content. J Pharmacol Exp Ther 236: 488-493.

15. Reen RK, Roesch SF, Kiefer F, Wiebel FJ, Singh J (1996) Piperine impairs cytochrome P4501A1 activity by direct interaction with the enzyme and not by down regulation of CYP1A1 gene expression in the rat hepatoma $5 \mathrm{~L}$ cell line. Biochem Biophys Res Commun 218: 562-569.

16. Volak LP, Ghirmai S, Cashman JR, Court MH (2008) Curcuminoids inhibit multiple human cytochromes P450, UDP-glucuronosyltransferase, and sulfotransferase enzymes, whereas piperine is a relatively selective CYP3A4 inhibitor. Drug Metab Dispos 36: 1594-1605.

17. Sambaiah K, Srinivasan K (1989) Influence of spices and spice principles on hepatic mixed function oxygenase system in rats. Indian J Biochem Biophys 26: 254-258.

18. Bhat BG, Chandrashekhar N (1987) Interaction of piperine with rat liver microsomes. Toxicology 44: 91-98.

19. Atal CK, Dubey RK, Singh J (1985) Biochemical basis of enhanced drug bioavailability by piperine: evidence that piperine is a potent inhibitor of drug metabolism. J Pharmacol Exp Ther 232: 258-262.

20. Reen RK, Wiebel FJ, Singh J (1997) Piperine inhibits aflatoxin Bl-induced cytotoxicity and genotoxicity in V79 Chinese hamster cells genetically engineered to express rat cytochrome P4502B1. J Ethnopharmacol 58: 165173

21. Koul S, Koul JL, Taneja SC, Dhar KL, Jamwal DS, et al. (2000) Structure activity 
relationship of piperine and its synthetic analogues for their inhibitory potentials of rat hepatic microsomal constitutive and inducible cytochrome P450 activities. Bioorg Med Chem 8: 251-268.

22. Pfund LY, Chamberlin BL, Matzger AJ (2015) The bioenhancer piperine is a least trimorphic. Cryst Growth Des 15: 2047-2051.

23. Zhao-Hui JIN, Wen QIU, Hui LIU, Jiang XH, Ling WANG (2018) Enhancement of oral bioavailability and immune response of Ginsenoside Rh2 by coadministration with piperine. Chinese J Nat Med 16: 143-149.

24. Lee SH, Kim HY, Back SY, Han HK (2018) Piperine-mediated drug interactions and formulation strategy for piperine: recent advances and future perspectives. Expert Opinion Drug Metab Tox 14: 43-57.

25. Singh S, Kumar $P$ (2017) Piperine in combination with quercetin halt 6 -OHDA induced neurodegeneration in experimental rats: Biochemical and neurochemical evidences. Neurosci Res 133: 38-47.

26. Thakur PS, Singh N, Sangamwar AT, Bansal AK (2017) Investigation of need of natural bioenhancer for a metabolism susceptible drug-raloxifene, in a designed self-emulsifying drug delivery system. AAPS PharmSciTech 18: 2529-2540.

27. Vora A, Patel S, Patel K (2016) Role of risorine in the treatment of drug susceptible pulmonary tuberculosis: a pilot study. J Assoc Physicians India 64 $20-24$

28. Atal S, Atal S, Vyas S, Phadnis P (2016) Bio-enhancing effect of Piperine with Metformin on lowering blood glucose level in Alloxan induced diabetic mice. Pharmacog Res 8: 56-60.

29. Khatri S, Awasthi R (2016) Piperine containing floating microspheres: an approach for drug targeting to the upper gastrointestinal tract. Drug Deliv Trans Res 6: 299-307.

30. Sethiya NK, Shah P, Rajpara A, Nagar PA, Mishra SH (2015) Antioxidant and hepatoprotective effects of mixed micellar lipid formulation of phyllanthin and piperine in carbon tetrachloride-induced liver injury in rodents. Food Func 6 : 3593-3603.

31. Di X, Wang X, Liu Y (2015) Effect of piperine on the bioavailability and pharmacokinetics of emodin in rats. J Pharm Biomed Anal 115: 144-149.

32. Zutshi U, Kaul JL (1982) The impact of Ayurvedic herbals on drug bioavailability. Indian Drugs 19: 476-479.

33. Zutshi U (1989) A process for the preparation of pharmaceutical combination with enhanced activity for treatment of tuberculosis and leprosy.

34. Bano G, Amla V, Raina RK, Zutshi U, Chopra CL (1987) The efect of piperine on pharmacokinetics of phenytoin in healthy volunteers. Planta Medica 53 : 568-569.

35. Shaikh J, Ankola DD, Beniwal V, Singh D, Kumar M (2009) Nanoparticle encapsulation improves oral bioavailability of curcumin by at least 9-fold when compared to curcumin administered with piperine as absorption enhancer. Eur J Pharm Sci 37: 223-230.

36. Gupta SK, Velpandian T, Sengupta S, Mathur P, Sapra P (1998) Influence of piperine on nimesulide induced antinociception. Phytotherapy Research 12 : $266-269$.

37. Karan RS, Bhargava VK, Garg SK (1999) Efect of trikatu on the pharmacokinetic profile of indomethacin in rabbits. Ind J Pharmacol 31: 160-161.

38. Mujumdar AM, Dhuley JN, Deshmukh VK, Naik SR (1999) Efect of piperine on bioavailability of oxyphenylbutazone in rats. Ind Drugs 36: 123-126.
39. Velpandian T, Jasuja R, Bhardwaj RK, Jaiswal J, Gupta SK (2001) Piperine in food: interference in the pharmacokinetics of phenytoin. Eur J Drug Metab Pharm 26: 241-247.

40. Pattanaik S, Hota D, Prabhakar S, Kharbanda P, Pandhi P (2006) Efect of piperine on the steady-state pharmacokinetics of phenytoin in patients with epilepsy. Phytotherapy Res 20: 683-686

41. Zutshi RK, Singh R, Zutshi U, Johri RK, Atal CK (1985) Influence of piperine on rifampicin blood levels in patients of pulmonary tuberculosis. J Ass Phys Ind 33: $223-224$

42. Lambert JD, Hong J, Kim DH, Mishin VM, Yang CS (2004) Piperine enhances the bioavailability of the tea polyphenol (-)-epigallocatechin-3-gallate in mice. J Nutr 134: 1948-1952.

43. Singh M, Varshneya C, Telang RS, Srivastava AK (2005) Alteration of pharmacokinetics of oxytetracycline following oral administration of Piper longum in hens. J Vet Sci 6: 197-200.

44. Balkrishna BS, Yogesh PV (2002) Influence of co-administration of piperine on pharmacokinetic profile of ciprofloxacin. Indian Drugs 39: 166-168.

45. Jin MJ, Han HK (2010) Efect of piperine, a major component of black pepper on the intestinal absorption of fexofenadine and its implication on food-drug interaction. J Food Sci 75: H93-H96.

46. Kasibhatta R, Naidu MUR (2007) Influence of piperine on the pharmacokinetics of nevirapine under fasting conditions: a randomised, crossover, placebocontrolled study. Drugs in R and D 8: 383-391.

47. Dama MS, Varshneya C, Dardi MS, Katoch VC (2008) Efect of trikatu pretreatment on the pharmacokinetics of pefloxacin administered orally in mountain Gaddi goats. J Vet Sci 9: 25-29.

48. Pattanaik S, Hota D, Prabhakar S, Kharbanda P, Pandhi P (2009) Pharmacokinetic interaction of single dose of piperine with steady-state carbamazepine in epilepsy patients. Phytotherapy Res 23: 1281-1286.

49. Janakiraman K, Manavalan R (2011) Studies on efect of piperine on oral bioavailability of ampicillin and norfloxacin. African $\mathrm{J}$ Trad Complementary Alt Med 5: 257-262.

50. Johnson JJ, Nihal M, Siddiqui IA, Scarlett CO, Bailey HH, et al. (2011) Enhancing the bioavailability of resveratrol by combining it with piperine. Mol Nutr Food Res 55: 1169-1176.

51. Patel S, Devada S, Patel H, Patel N, Bhavsar S, et al. (2011) Influence of coadministration of piperine on pharmacokinetic profile of gatifloxacin in layer birds. Global Veterinaria 7: 427-432.

52. Singh A, Chand S (2011) Improved bioavailability of atenolol with piperine in rats. Int J Pharm Res 3: 88-91.

53. Venkatesh S, Durga KD, Padmavathi Y, Reddy BM, Mullangi R (2011) Influence of piperine on ibuprofen induced antinociception and its pharmacokinetics. Drug Res 61: 506-509.

54. Singh A, Jain DA, Kumar S, Jaishwal N, Singh RK, et al. (2012) Enhanced bioavailability of losartan potassium with piperine in rats. Int $\mathrm{J}$ Pharm Res Tech 2: 34-36. 